\title{
The Centre for Excellence in Teaching (CET) at Portucalense University: goals, strategies and expected outcomes.
}

Fernandes, Sandra ${ }^{a}$; Morais, Paulab; Mesquita, Diana ${ }^{c}$; Abelha, Marta ${ }^{\text {a,d }}$; Fernandes, Sara $^{a}$ and Albuquerque, Ana Sílvia ${ }^{a}$

${ }^{a}$ Portucalense Institute for Human Development (INPP), Portucalense University, Portugal, ${ }^{\mathrm{b}}$ Research on Economics, Management and Information Technologies (REMIT), Portucalense University, Portugal, ' University of Minho, Portugal, d Centro de Estudos Interdisciplinares do Século XX - CEIS20, University of Coimbra, Portugal.

\begin{abstract}
This paper presents part of the change process carried out at the Portucalense University (UPT), Portugal, aimed at promoting student centred teaching and learning. To attain this goal, the Centre for Excellence in Teaching (CET) was created to support academic staff development, provide pedagogic training for teachers, create pedagogical resources and enhance the dissemination of best practices and teaching quality at UPT. The preliminary results of the implementation of the activities developed by the CET reveal a positive participation and involvement of academic staff, according to data collected through an online questionnaire to participants. Teachers showed interest in developing active learning strategies and openness to change their teaching practices. Some examples of the activities implemented by teachers, in the first semester of 2017/2018, are briefly presented in this paper.
\end{abstract}

Keywords: teaching and learning; quality; pedagogic training; active learning; PBL. 


\section{Introduction}

The shift of paradigm towards student centred learning and teaching is a key issue of the European Standards and Guidelines for Quality Assurance in Higher Education (ESG) (Belgium, 2015), a key reference document for internal and external quality assurance in Higer Education. According to this framework, it is possible to identify two important standards for internal quality assurance, namely:

- Institutions should ensure that the programmes are delivered in a way that encourages students to take an active role in creating the learning process, and that the assessment of students reflects this approach.

- Institutions should assure themselves of the competence of their teachers.

Therefore, the constructive aligment between student centred learning, teaching and assessment (Biggs, 1996; Biggs \& Tang, 2011) and the professional development and training of teaching staff must be at the heart of the implementation of any change process that aims to promote quality in teaching and learning in higher education.

Some of the guidelines pointed out in the document, concerning the teaching and learning environments, include the following characteristics (ESG, 2015, p. 12):

“- respects and attends to the diversity of students and their needs, enabling flexible learning paths;

- considers and uses different modes of delivery, where appropriate;

- flexibly uses a variety of pedagogical methods;

- regularly evaluates and adjusts the modes of delivery and pedagogical methods;

- encourages a sense of autonomy in the learner, while ensuring adequate guidance and support from the teacher;

- promotes mutual respect within the learner-teacher relationship;

- has appropriate procedures for dealing with students’ complaints”.

In regard to the teaching staff, the ESG refers to the need to build an environment that offers opportunities for and promotes the professional development of teaching staff, encourages scholarly activity to strengthen the link between education and research and, finally, encourages innovation in teaching methods and the use of new technologies. 
This paper presents part of the change process carried out at the Portucalense University, Portugal, aimed at promoting student centred teaching and learning. To attain this goal, the Centre for Excellence in Teaching (CET) was created to support academic staff in the achievement of this outcome.

\section{Context of the study - Portucalense University}

Portucalense University (UPT) is a private higher education institution, located in Oporto, in the north of Portugal. It is organized in four Departments: Law, Economics, Management and Informatics, Heritage and Tourism and Psychology and Education that teach 1st and 2nd cycle programmes and post graduations, structured according to the Bologna Process. More than acquiring theoretical knowledge, the students have the chance to develop practical work and research projects, developing different kinds of skills that prepare them for jobs in future career and for living in a competitive global society. Programmes are structured so as to respond flexibly to changing labor market needs, through various teaching methods empirically based on significant case studies whenever applicable. UPT has its own exclusive staff and also counts on the input from external professionals from different industrial and commercial sectors, through seminars with guests on various themes, promoting its relationships with the corporate world with the goal of preparing students for the future professional demands.

As part of the continuous improvement goal within the teaching and learning process, it is part of the institution's objectives that teachers use methodologies aimed at the active participation of students, methodologies aimed at preparing students for research, activities developed within the curricular units which promote students skills in different areas and deepen students' approach to the labour market (mini-internships, projects in partnership with entreprises, action-research projects, among others). The diversity of scientific areas in which teachers teach associated with the different realities as to the type and number of students per class present greater challenges for the accomplishment of this objective.

It is, therefore, a concern of the Rector's Office to promote teacher training and professional development in multiple areas: pedagogical and curricular, languages, training management, personal and social skills that allow them to update in the most diverse areas of teaching and learning, as well as acquire significant tools to develop research, mentoring and teaching tasks.

The Center for Excellence in Teaching (CET), created in 2017, is one of the institutional strategies carried out by the Rectory in order to attain the pedagogical challenges faced by higher education European institutions. 


\section{The Centre for Excellence in Teaching (CET) at Portucalense University}

The CET was created within the scope of promoting excellence and improvement of teaching and learning at UPT. The aims and core activities of this centre are aligned with other institutional bodies of the university, such as the Pedagogic Council and the Evaluation and Quality Assurance Office at UPT.

Amongst the several activities that CET intends to promote to enhance the quality of teaching and learning at UPT, one of the main acivities is the development of pedagogic training sessions for academic staff. These sessions are designed, organized and developed according to teachers' individual motivations, interests and needs, previously collected through an online survey.

\section{Aim and goals}

The objectives of the CET include the following:

- $\quad$ To promote pedagogic training for academic staff;

- $\quad$ To develop pedagogical resources and publications;

- $\quad$ To create a website for the dissemination of best practices and for the recognition of teaching quality at UPT.

The CET aims to:

- $\quad$ Recongnize the importance of pedagogical training for the quality of teaching and learning;

- $\quad$ Respond to the individual needs of academic staff, in terms of training areas;

- $\quad$ Develop strategies that promote the reflection on teaching practices;

- $\quad$ Create a network for the discussion of teaching practices and experiences;

- $\quad$ Disseminate examples of good teaching practices at UPT.

\section{Preliminary Results}

\section{Pedagogic Training for Academic Staff}

An online survey of Classroom Teaching Methods (Bonwell, 1991) was used to collect data from teachers in regard their teaching methods and also to identify teachers' motivation to participate in pedagogic training. The results of the survey $(n=65)$ indicated that teachers were interested in learning more about active learning (92,3\%). Therefore, during the months of june and july, corresponding to the end of the academic year, three training sessions with the duration of 3 hours each were developed about the theme of active learning (Prince, 1994). An external expert, both on education sciences and on coaching for 
higher education teachers, was responsible for preparing the training sessions, with the support and guidance of the coordination team of the CET.

Most of the teachers who participated in the pedagogic training sessions $(n=27)$ reported that they introduced changes in the classroom, regarding the strategies used - some examples: Kahoot (flipped classroom), Think-Pair-Share, PBL (Problem and Project) and Simulation. The motivation to change and the attempt shown by the participating teachers, as well as the level of critical reflection shown during the discussion about their teaching practices, are important issues to highlight as results from this first implementation.

The experiences carried out vary in terms of application, according to the level of systematization of the pedagogical approach. That is, in some cases the changes introduced were still of exploratory nature, without great impact, for example, changes in the assessment method; in other cases, deeper changes with impact on pedagogical and curricular practice were verified. However, it is important to stress the diversity of experiences shared by teachers, in their own voices. This represents a significant milestone in the CET's activity, crucial for the professional development of teachers.

\section{A case of PBL implemented in 2017/2018}

An example of a pedagogical approach implemented by a group of teachers from the Department of Psychology and Education was based on Project-based Learning - PBL. The pilot experience of PBL methodology was applied in the 2nd year of the Social Education programme at UPT (Fernandes, Abelha, Fernandes \& Albuquerque, 2018).

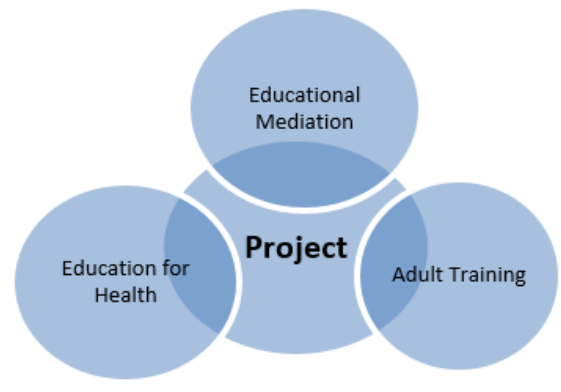

Figure 1. Curricular Units participating in the PBL Project of 2017/2018

In the first semester of the academic year of 2017/2018, an interdisciplinary project was developed within three curricular units namely, "Adult Education", "Education for Health" and "Educational Mediation", under the theme of addictive behaviors and dependencies. The selected theme for the project integrated the learning outcomes specific to each of the 
three courses, as well as their assessment methods, in a common project that allowed the curricular articulation and the development of a set of transversal competences considered as fundamental for student success.

Students and teachers perceptions were collected, both at the beginning and at the end of the PBL approach, revealing a positive view of the role of the project to enhance student centred teaching and learning.

Creativity, oral and written communication, problem solving, project management, interpersonal and teamwork skills were key competencies highlighted by students as a result of the PBL project. This also resulted in a greater capacity of autonomy and the development of a more active role of students in their own learning, characteristics which are in accordance with the main guidelines of European Standards and Guidelines for Quality in Higher Education (2015).

Constrainst related to time management and adaptation to the PBL methodology were pointed out by the students as the main problems felt in an early stage of the project. These difficulties were overcome with the increase of confidence and experience in the development of PBL methodology.

In addition to improving the teaching and learning process, the PBL methodology has positive aspects, according to the three teachers who participated in the approach. Findings from teachers highlight the following advantages of the PBL approach:

a) promoting collaborative work amongst teachers, that attenuate any fears regarding methodologies of an innovative nature for the generality of the participant teachers;

b) greater curricular articulation, culminating in an integrated project of three courses;

c) increased confidence by teachers on their work;

d) shared responsibilities by teachers in a complementary way;

e) improving the quality of student learning, as it encourages risk taking and diversification of teaching methodologies.

Regarding the less positive aspects or difficulties found, teachers identify difficulties in the coordination of the time schedules and lack of time, motivated by the number of additional tasks assumed by each teacher. 


\section{Final Remarks}

In general, the activities developed by CET at the Portucalense University have shown a positive participation and involvement of academic staff. Teachers are interested in improving teaching and learning and have shown openness to change their teaching practices. The examples reported briefly on this paper contribute to confirm this outcome.

During one of the follow-up sessions carried out by CET, after the implementation of the active learning strategies in the first semester of the academic year of 2017/2018, the teachers also referred to the constraints and difficulties faced when introducing changes to their teaching and learning practices in the classroom. For this reason, it was considered important that teachers collect data from students to better understand their motivations, difficulties and mindset, when introducing changes to the traditional teaching and learning environment. Some of the issues and constrainsts referred by teachers, based on the notes collected from the external teacher trainer, can be summarized in the three major topics:

- $\quad$ Student mindset: the way students face the challenges proposed, time management by students, class attendance, etc. - Preparing students since the first day at the university is a fundamental issue to change student mindset. Perhaps the starting point is to clarify: What is the student profile that UPT wants to develop? And based on this, UPT should prepare, together with all the stakeholders (teachers, partners, etc.), curricular opportunities and other academic experiences that allow all students to develop the skills associated with this profile.

- $\quad$ Class attendance: this appears to be one of the major difficulties for some teachers, to the point that it even limited the implementation or conclusion of the innovative straegies developed in some contexts. However, the position that UPT should assume based on this attitude demonstrated by students is not consensual amongst teachers. This topic deserves greater reflection and a specific time and space for the joint discussion, was one of the conclusions drawn by teachers.

- $\quad$ "It did not work": for some teachers, the new strategies implemented simply did not work (eg. Kahoot in the Psychology programme, student involvement in the definition of questions for a test, the inclusion of a new curricular unit within an interdisciplinary project, etc.). These situations should be further analyzed case-by-case in order to better understand the constraints and create alternatives and other solutions with the aim of improving teaching and learning. This is a fundamental issue for teacher motivation.

Future work of CET should focus on continuing improving teaching and learning through academic staff development and training, which can be complemented by other activities that can involve greater student participation in the reflection process. It is important to understand students' point of view, what do they think about these changes, what do they 
consider that is important to change. In sum, student involvement is a crucial step to take CET to a higher level.

\section{References}

Biggs, J., \& Tang, C. (2011). Teaching for quality learning at university: what the student does (4th ed.). Buckingham: Open University Press/McGraw Hill.

Biggs, J. (1996). Enhancing teaching through constructive alignment. Higher Education, 32(3), 347-364.

Bonwell, C., \& Eison, J. (1991). Active Learning: Creating Excitement in the Classroom. ASHE-ERIC Higher Education Reports. Washington DC: ERIC Clearinghouse on Higher Education.

ENQA, ESU, EUA \& EURASHE (2015). Standards and Guidelines for Quality Assurance in the European Higher Education Area (ESG). Brussels, Belgium.

Fernandes, S., Abelha, M., Fernandes, S. \& Albuqerque, A. S. (2018). Implementation of $\mathrm{PBL}$ in a Social Education Programme at the Portucalense University. In PAEE/ALE2018 Conference Proceedings. 28fev-2mar, Brasília, Brasil. (accepted for publication).

Prince, M. (2004). Does active learning work? A review of the research. Journal of Engineering Education, 93 (3), 223-231. 